\title{
JURNAL
}

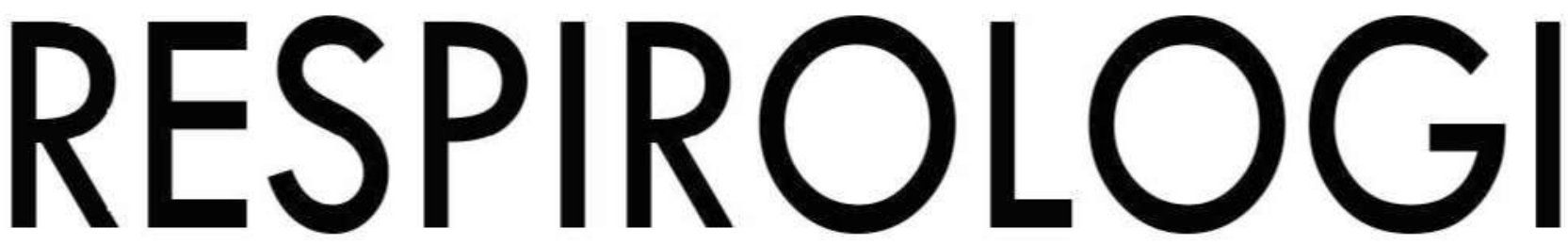

Majalah Resmi Perhimpunan Dokter Paru Indonesia Official Journal of The Indonesian Society of Respirology

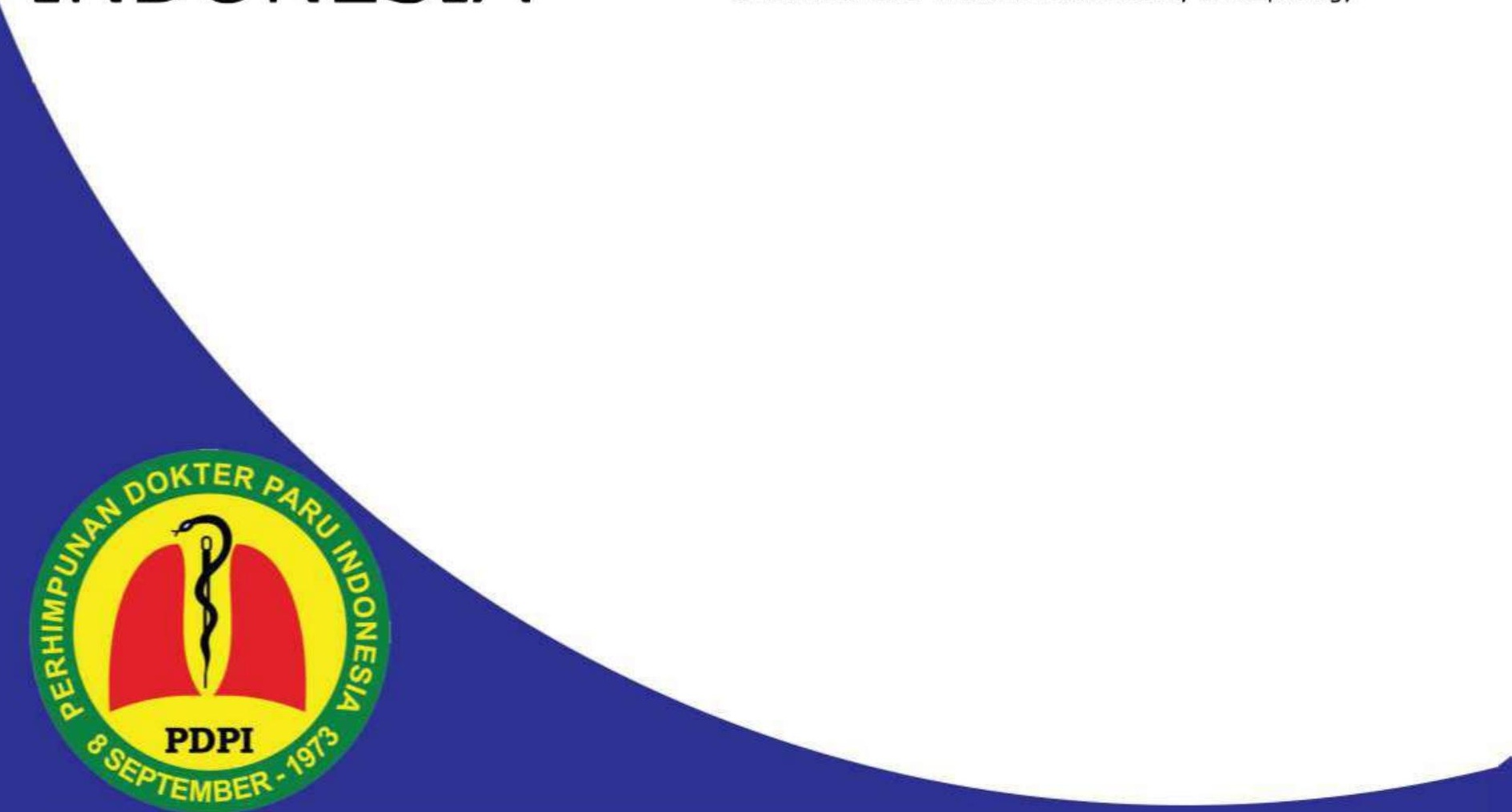

Pengaruh Latihan Pursed Lips Breathing dan Pernapasan Diafragma terhadap Spirometri dan Skala Modified Medical Research Council pada Penyakit Paru Obstruktif Stabil

Protein C-Reaktif Sensitivitas Tinggi sebagai Penanda Inflamasi Sistemik Penyakit Jantung Koroner pada Subjek Pria dengan Apnea Tidur Obstruktif

Kalsifikasi Arteri Koroner di CT Scan Toraks sebagai Prediktor Penyakit Jantung Koroner pada Pasien Kanker Paru

Proporsi Rinitis Alergi pada Asma dan Hubungannya dengan Derajat Kontrol Asma

Pengaruh Pajanan Debu Alumunium terhadap Gangguan Fungsi Paru

Pengaruh Senam Asma terhadap Nitrit Oksida Darah, Mood, Energy Expenditure dan Kualitas Seks

Hubungan Lama Pajanan Polusi Udara dengan Kejadian Emfisema berdasarkan Pemeriksaan CT Scan Toraks pada Sopir Angkutan Kota

Efektivitas Rope Jumping dan Latihan Tabata terhadap Fungsi Paru dan Indeks Kebugaran Tubuh

Tingkat Akurasi Pemeriksaan Ultrasonografi Paru pada Diagnosa Pneumonia: Evidence-Based Case Report

Keberhasilan Tata Laksana Pasien COVID-19 dengan ARDS Berat Menggunakan Terapi Standar 


\title{
JURNAL
}

\author{
RESPIROLOGI \\ INDONESIA \\ Majalah Resmi Perhimpunan Dokter Paru Indonesia \\ Official Journal of The Indonesian Society of Respirology
}

\section{SUSUNAN REDAKSI}

Penasehat

M. Arifin Nawas

Faisal Yunus

Agus Dwi Susanto

Penanggung Jawab / Pemimpin Redaksi

Fanny Fachrucha

Wakil Pemimpin Redaksi

Winariani

\section{Anggota Redaksi}

Feni Fitriani

Amira Permatasari Tarigan

Jamal Zaini

Farih Raharjo

Mia Elhidsi

Ginanjar Arum Desianti

Irandi Putra Pratomo

\section{Sekretariat}

Nindy Audia Nadira

Suwondo

SST : Surat Keputusan Menteri Penerangan RI

No.715/SK/DitjenPPG/SST/1980 Tanggal 9 Mei 1980

\section{Alamat Redaksi}

PDPI Jl. Cipinang Bunder, No. 19, Cipinang Pulo Gadung

Jakarta Timur 13240 Telp: 02122474845

Email : editor@jurnalrespirologi.org

Website : http://www.jurnalrespirologi.org

\section{Diterbitkan Oleh}

Perhimpunan Dokter Paru Indonesia (PDPI)

Terbit setiap 3 bulan (Januari, April, Juli \& Oktober)

\section{Jurnal Respirologi Indonesia}

Akreditasi Peringkat 2

Sesuai Keputusan Menteri Riset dan Teknologi/Kepala Badan

Riset dan Inovasi Nasional Republik Indonesia

Nomor: 200/M/KPT/2020 Tanggal 23 Desember 2020 


\title{
JURNAL \\ RESPIROLOGI \\ INDONESIA \\ Majalah Resmi Perhimpunan Dokter Paru Indonesia \\ Official Journal of The Indonesian Society of Respirology
}

\author{
VOLUME 41, NOMOR 2, April 2021
}

\section{DAFTAR ISI}

Artikel Penelitian

Pengaruh Latihan Pursed Lips Breathing dan Pernapasan Diafragma terhadap Spirometri dan Skala Modified Medical Research Council pada Penyakit Paru Obstruktif Stabil

Ida Muna Junita, Mulyadi, Teuku Zulfikar, Nurrahmah Yusuf

Protein C-Reaktif Sensitivitas Tinggi sebagai Penanda Inflamasi Sistemik Penyakit Jantung Koroner pada Subjek Pria dengan Apnea Tidur Obstruktif

Allen Widysanto, Audrey Suryani Soetjipto, Michelle Widysanto

Kalsifikasi Arteri Koroner di CT Scan Toraks sebagai Prediktor Penyakit Jantung Koroner pada

Pasien Kanker Paru

Luths Maharina, Yusup Subagio Sutanto, Widiastuti, Sulistyani Kusumaningrum, Adam Prabata, Hari Wujoso

Proporsi Rinitis Alergi pada Asma dan Hubungannya dengan Derajat Kontrol Asma

Fersia Iranita Liza, Wiwien Heru Wiyono, Deasi Anggraini, Erlang Samoedro, Triya Damayanti

Pengaruh Pajanan Debu Alumunium terhadap Gangguan Fungsi Paru

Rinto Mangitua Hutapea, Novrikasari, Mona Lestari, Anita Camelia, Desheila Andarini, Rizka Faliria Nandini

Pengaruh Senam Asma terhadap Nitrit Oksida Darah, Mood, Energy Expenditure dan Kualitas Seks Ita Juliastuti, Suradi, Debree Septiawan

Hubungan Lama Pajanan Polusi Udara dengan Kejadian Emfisema berdasarkan Pemeriksaan CT

Scan Toraks pada Sopir Angkutan Kota Yopi Simargi, Jessica Seprianto, Bryany Titi Santi

Efektivitas Rope Jumping dan Latihan Tabata terhadap Fungsi Paru dan Indeks Kebugaran Tubuh Stella Tinia Hasianna, Oeij Anindita Adhika, Kartika Dewi, Adra Taufiqah, Ajeng Mira Ayuningsih

Tinjauan Pustaka

Tingkat Akurasi Pemeriksaan Ultrasonografi Paru pada Diagnosa Pneumonia: Evidence-Based Case Report

Adityo Wibowo, Airin Aldiani, Faiza Hatim, Galoeh Adyasiwi, Hendra Wahyuni MS, Khairunnisa Imaduddin, Malsephira Hasmeryasih, Mega Juliana, Nesia Priandari, Nina Ratu Nur Kharima, Rudy Satriawan, Agus Dwi Susanto 


\title{
KALSIFIKASI ARTERI KORONER DI CT SCAN TORAKS SEBAGAI PREDIKTOR PENYAKIT JANTUNG KORONER PADA PASIEN KANKER PARU
}

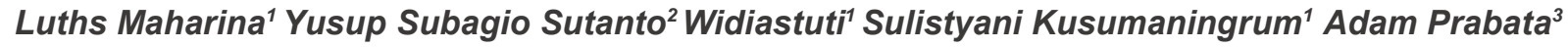 \\ Hari Wujoso ${ }^{4}$
${ }^{1}$ Departemen Radiologi Fakultas Kedokteran Universitas Sebelas Maret, RSUD Dr. Moewardi, Surakarta
${ }^{2}$ Departemen Pulmonologi dan Kedokteran Respirasi Fakultas Kedokteran Universitas Sebelas Maret, RSUD Dr. Moewardi, Surakarta
${ }^{3}$ Departemen Penyakit Dalam Divisi Kardiovaskuler Fakultas Kedokteran Universitas Kobe, Jepang
${ }^{4}$ Departemen Forensik dan Medikolegal Fakultas Kedokteran Universitas Sebelas Maret, RSUD Dr. Moewardi, Surakarta

\begin{abstract}
Abstrak
Pendahuluan: Kanker paru diketahui memiliki asosiasi kuat dengan penyakit kardiovaskular, salah satunya adalah penyakit jantung koroner. Rokok yang menjadi faktor risiko utama kanker paru dan penyakit jantung koroner diduga kuat sebagai alasan terdapatnya asosiasi tersebut. Penelitian ini bertujuan untuk mengetahui kemampuan prediksi temuan kalsifikasi arteri koroner berdasarkan CT Scan toraks dengan prevalensi penyakit jantung koroner pada pasien kanker paru.

Metode: Penelitian ini merupakan studi potong lintang dengan metode consecutive sampling. Subjek penelitian ini adalah dewasa ( $\geq 18$ tahun) serta terdiagnosis kanker paru berdasarkan pemeriksaan histopatologi.

Hasil: Empat puluh subjek dengan kanker paru yang menjalani pemeriksaan rutin CT scan toraks menjadi subjek penelitian ini. Pasien kanker paru dengan temuan kalsifikasi arteri koroner pada CT scan toraks memiliki risiko lebih tinggi untuk memiliki penyakit jantung koroner sebesar 73 kali lebih tinggi $(O R=72,63 ; I K ~ 95 \%=3,81-1386,21 ; P=0,004)$. Selain itu, pasien kanker paru yang masih dan bekas perokok berisiko 46 kali lebih tinggi untuk memiliki penyakit jantung koroner (OR=45,75; IK 95\%=1,14-1987,62; $\mathrm{P}=0,043)$. Temuan kalsifikasi arteri koroner pada CT scan toraks memiliki sensitivitas $86,7 \%$, spesifisitas $80,0 \%$, NPP 72,2\% dan NPN 90,9\% untuk memprediksi penyakit jantung koroner pada pasien kanker paru.

Kesimpulan: Kalsifikasi arteri koroner berdasarkan hasil CT scan toraks dapat digunakan sebagai prediktor terdapatnya penyakit jantung koroner pada pasien kanker paru, terutama yang masih dan bekas perokok. Penelitian lebih ekstensif di masa depan masih dibutuhkan untuk memperkuat temuan ini.

Kata Kunci: kalsifikasi arteri koroner, kanker paru, penyakit jantung koroner, perokok
\end{abstract}

\section{CORONARY ARTERY CALSIFICATION ON CHEST CT SCAN AS CORONARY HEART DISEASE PREDICTOR IN LUNG CANCER PATIENTS}

\begin{abstract}
Background: Lung cancer is widely known has strong association with cardiovascular diseases, including coronary heart disease. Smoking as the main risk factor for lung cancer and coronary artery disease is strongly hypothesized as reason behind this association. Our study aimed to predict ability of coronary artery calcification based on chest CT in prevalence of coronary heart disease in patients with lung cancer. Method: This study had cross-sectional design with consecutive sampling method. Subjects in this study were adults ( $\geq 18$ years old) with lung cancer based on histopathological examination.

Result: Forty subjects with lung cancer who undergone chest CT was selected as samples in this study. After calculated with other factors, patients with lung cancer who also had coronary artery calcification lesions in Chest CT had 73 times higher risk to develop coronary heart disease $(O R=72.63 \% ; 95 \% \mathrm{Cl}=3.81-1386.21 ; P=0.004)$. In addition, lung cancer subjects who are current and ex-smoker had 46 times higher risk to develop coronary heart disease $(O R=45.75 ; 95 \% \mathrm{Cl}=1.14-1987.62 ; P=0.043)$. Based on those findings, coronary artery calcification has $86.7 \%$ sensitivity, $80.0 \%$ specificity, $72.2 \%$ PPV and $90.9 \%$ NPV for predicting coronary heart disease in lung cancer patients.

Conclusion: Coronary artery calcification based on chest CT can be utilized as coronary heart disease predictor in lung cancer patients, especially who are current and ex-smoker. Extensive studies, is needed for strengthen this finding in near future.

Keywords: coronary artery calcification, lung cancer, coronary heart disease, smoker
\end{abstract}

Korespondensi: Luths Maharina

Email: luths_radiologi20171@student.uns.ac.id 


\section{PENDAHULUAN}

Kanker paru merupakan penyakit yang diketahui berhubungan dengan penyakit kardiovaskular. ${ }^{1}$ Pasien dengan kanker paru juga diketahui memiliki risiko lebih tinggi untuk mengalami penyakit kardiovaskular. ${ }^{1-4}$

Penyakit kardiovaskular sudah lama diketahui sebagai salah satu penyebab mortalitas yang tidak terkait kanker pada pasien kanker paru, terutama penyakit jantung koroner (PJK). ${ }^{5}$ Asosiasi tersebut diduga terkait dengan riwayat merokok, bahkan perokok pasif, diketahui sebagai faktor risiko utama terjadinya kanker paru dan PJK. 2,6 Rokok yang mengandung banyak zat karsinogen diketahui menyebabkan stress oksidatif dan inflamasi yang kemudian memicu proliferasi sel epitel paru yang tidak terkontrol sehingga berujung pada kanker

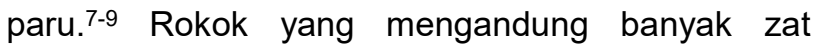
proaterogenik memiliki hubungan yang erat dengan PJK dengan cara berkontribusi pada fase awal aterogenesis melalui peningkatan oklusi arteri koroner dengan menyebabkan disrupsi endotel dan adhesi platelet ke lapisan subintima pembuluh darah yang berujung pada PJK. .0-13 $^{10}$

\section{Computed Tomography (CT) Scan toraks} merupakan pemeriksaan rutin untuk pasien kanker paru yang juga dapat digunakan untuk mengetahui risiko PJK. ${ }^{14-16}$ Melalui CT scan toraks, lesi kalsifikasi pada arteri koroner dapat diketahui dan dikuantifikasi untuk mengetahui derajat keparahannya dan sebagai panduan untuk kebutuhan tindakan. ${ }^{14,17,18}$ Pemeriksaan ini juga dapat dilakukan tanpa injeksi kontras intravena dan dosis radiasi rendah, sehingga dapat menjadi pilihan untuk mengetahui risiko PJK pada pasien kanker paru tanpa menambah pajanan radiasi. ${ }^{14}$

Penelitian mengenai kemampuan prediksi temuan kalsifikasi arteri koroner dari pemeriksaan CT scan toraks terhadap terjadinya PJK pada pasien kanker paru sudah pernah dilakukan pada populasi Amerika dan Eropa, namun masih minim di Asia, bahkan belum pernah dilakukan di Indonesia. Pada penelitian ini, peneliti ingin mengetahui hubungan antara ditemukannya lesi kalsifikasi pada arteri koroner berdasarkan hasil pemeriksaan CT scan toraks dengan kejadian PJK pada pasien dengan kanker paru pada populasi orang Indonesia.

\section{METODE}

Penelitian ini adalah studi uji diagnostik dengan desain potong lintang yang diselenggarakan di RSUD Dr. Moewardi Surakarta. Pemeriksaan CT scan toraks dilakukan di Departemen Radiologi RSUD Dr. Moewardi Surakarta. Penelitian ini dilaksanakan selama 6 bulan yaitu dalam rentang Januari hingga Juni 2020. Penelitian ini telah mendapatkan izin dari Komisi Etik Rumah Sakit Dr. Moewardi dan Fakultas Kedokteran Universitas Negeri Sebelas Maret.

Penelitian ini menggunakan data sekunder yang diambil dari rekam medis pasien kanker paru yang sedang menjalani perawatan di RSUD Dr. Moewardi Surakarta.

Subjek penelitian ini berjumlah 40 orang yang dipilih menggunakan teknik consecutive sampling. Subjek dipilih dengan kriteria inklusi usia $\geq 18$ tahun, terdiagnosis kanker paru berdasarkan pemeriksaan histopatologi, serta riwayat merokok, tinggi badan, berat badan, hiperkolesterolemia, dan hipertensi. Kriteria eksklusi pada penelitian ini adalah pasien dengan riwayat alergi obat serta memiliki kadar kreatinin darah $\geq 2 \mathrm{mg} / \mathrm{dl}$ sehingga tidak dapat dapat dilakukan pemeriksaan CT scan toraks dengan kontras.

Pemeriksaan CT scan toraks pada penelitian ini dilakukan menggunakan mesin CT scan Toshiba Aquilion 64 slice. CT scan toraks dilakukan dengan dan tanpa kontras. Kontras yang digunakan adalah lopamidol 300 atau 370, bergantung pada berat badan subjek.

Hasil CT scan toraks dengan dan tanpa kontras dikombinasikan untuk dianalisis untuk menentukan adanya kalsifikasi arteri koroner. Temuan kalsifikasi pada rentang 90-200 Hounsfield Unit (HU) spesifik di area arteri koroner dianggap sebagai hasil positif kalsifikasi arteri koroner.

Hubungan antara temuan kalsifikasi arteri koroner pada pemeriksaan CT scan toraks dengan prevalensi PJK dianalisis dengan regresi logistik. Analisis regresi logistik dilakukan antara variabel 
temuan PJK dengan beberapa variabel lain selain kalsifikasi arteri koroner, antara lain jenis kelamin, usia, riwayat merokok, obesitas, hiperkolesterolemia dan hipertensi.

Analisis sensitivitas, spesifisitas, nilai prediksi positif (NPP) dan nilai prediksi negatif (NPN) dilakukan melalui analisis tabel $2 \times 2$ antara temuan kalsifikasi arteri koroner dengan prevalensi PJK. Semua analisis statistik dilakukan menggunakan aplikasi SPSS 25.0.

\section{HASIL}

\section{Karakteristik subjek}

Penelitian ini melibatkan 40 pasien kanker paru yang telah menjalani pemeriksaan CT scan toraks di RS Dr. Moewardi Surakarta. Berdasarkan kelompok usia, terdapat $2(5,0 \%)$ orang yang berusia $<40$ tahun, $6(15,0 \%)$ orang yang berusia $40-49$ tahun, 15 (37,5\%) yang berusia 50-59 tahun, dan 17 $(42,5 \%)$ orang yang berusia $>60$ tahun. Berdasarkan jenis kelamin, terdapat $19(47,5 \%)$ orang laki-laki dan $21(52,5 \%)$ orang perempuan.

Pasien kanker paru pada penelitian ini terdiri atas $38(94,5 \%)$ kasus kanker paru karsinoma bukan sel kecil (KPKBSK) dengan adenokarsinoma sebanyak $35(87,5 \%)$ kasus dan karsinoma sel skuamosa (KSS) sebanyak $3 \quad(7,5 \%)$ kasus. Berdasarkan stadium TNM, pada penelitian ini ditemukan $0(0 \%)$ kasus dengan stadium I-III dan 40 $(100 \%)$ orang dengan stadium IV dengan rincian 12 (30\%) orang dengan stadium IVA dan 28 (70\%) orang dengan stadium IVB.

Pasien dengan hiperkolesterolemia ditemukan $14(35,0 \%)$ orang, sedangkan terdapat $26(65,0 \%)$ orang tanpa hiperkolesterolemia. Terdapat $8(20,0 \%)$ orang dengan hipertensi grade 2, $17(42,5 \%)$ orang dengan hipertensi grade 1 , dan $15(37,5 \%)$ orang tanpa hipertensi.

Terdapat $15(37,5 \%)$ orang dengan diagnosis PJK dan $25(62,5 \%)$ orang tanpa diagnosis PJK. Berdasarkan pemeriksaan CT scan, terdapat 18 $(45,0 \%)$ orang dengan kalsifikasi arteri koroner dan $22(55,0 \%)$ orang tanpa kalsifikasi arteri koroner (Tabel 1).

\begin{tabular}{|c|c|c|}
\hline Variabel & Jumlah (n) & Persentase (\%) \\
\hline \multicolumn{3}{|l|}{ Usia } \\
\hline$<40$ tahun & 2 & 5,0 \\
\hline 40-49 tahun & 6 & 15,0 \\
\hline 50-59 tahun & 15 & 37,5 \\
\hline$>60$ tahun & 17 & 42,5 \\
\hline \multicolumn{3}{|l|}{ Jenis Kelamin } \\
\hline Laki-laki & 19 & 47,5 \\
\hline Perempuan & 21 & 52,5 \\
\hline \multicolumn{3}{|l|}{ Tipe Kanker paru } \\
\hline KPKBSK & 38 & 94,5 \\
\hline Adeno $\mathrm{Ca}$ & 35 & 87,5 \\
\hline KSS & 3 & 7,5 \\
\hline KPKSK & 2 & 5,0 \\
\hline \multicolumn{3}{|l|}{ Stadium Kanker } \\
\hline I & 0 & 0 \\
\hline II & 0 & 0 \\
\hline III & 0 & 0 \\
\hline IVA & 12 & 30,0 \\
\hline IVB & 28 & 70,0 \\
\hline \multicolumn{3}{|l|}{ Hiperkolesterolemia } \\
\hline Ada & 14 & 35,0 \\
\hline Tidak ada & 26 & 65,0 \\
\hline \multicolumn{3}{|l|}{ Hipertensi } \\
\hline Hipertensi Grade 2 & 8 & 20,0 \\
\hline Hipertensi Grade 1 & 17 & 42,5 \\
\hline Tidak ada & 15 & 37,5 \\
\hline \multicolumn{3}{|l|}{ Obesitas } \\
\hline Ada & 14 & 35,0 \\
\hline Tidak ada & 26 & 65,0 \\
\hline \multicolumn{3}{|l|}{ Riwayat Merokok } \\
\hline Masih merokok & 9 & 22,5 \\
\hline Bekas perokok & 9 & 22,5 \\
\hline Tidak merokok & 22 & 55,0 \\
\hline \multicolumn{3}{|l|}{ PJK } \\
\hline Ada & 15 & 37,5 \\
\hline Tidak ada & 25 & 62,5 \\
\hline \multicolumn{3}{|l|}{ Kalsifikasi Arteri } \\
\hline \multicolumn{3}{|l|}{ Koroner } \\
\hline Ada & 18 & 45,0 \\
\hline Tidak ada & 22 & 55,0 \\
\hline
\end{tabular}

Hubungan antara temuan kalsifikasi arteri koroner dengan prevalensi penyakit jantung koroner pada pasien kanker paru

Pada penelitian ini, kami menemukan terdapat hubungan yang bermakna secara statistik antara diagnosis PJK pada pasien kanker paru dengan kalsifikasi arteri koroner, jenis kelamin dan riwayat merokok. Kami tidak menemukan hubungan yang bermakna pada obesitas, hiperkolesterolemia, hipertensi dan usia, dengan diagnosis PJK pada kanker paru. 
Temuan kalsifikasi arteri koroner berdasarkan hasil pemeriksaan CT scan meningkatkan risiko diagnosis PJK pada pasien kanker paru sebesar 72,63 kali lebih tinggi secara bermakna (OR=111,48; Indeks Kepercayaan 95\% $=5,10-2437,37 ; P=0,004)$. Jenis kelamin laki-laki menurunkan risiko diagnosis PJK pada pasien kanker paru sebesar 0,01 kali dibandingkan perempuan secara bermakna (IK $95 \%<0,01-0,81 ; P=0,040)$.

Pasien yang masih/pernah merokok memiliki risiko diagnosis penyakit jantung koroner pada pasien kanker paru sebesar 47,53 kali lebih tinggi secara bermakna (IK 95\%=1,14-1987,62; $P=0,043$ ). Obesitas dapat meningkatkan risiko diagnosis PJK pada pasien kanker paru sebesar 4,19 kali lebih tinggi, namun tidak bermakna secara statistik (IK $95 \%=0,30-57,61 ; P=0,285)$.

Hiperkolesterolemia meningkatkan risiko diagnosis PJK pada pasien kanker paru sebesar 3,24 kali lebih tinggi, namun tidak bermakna secara statistik (IK 95\%=0,36-29,32; $P=0,295$ ). Hipertensi menurunkan risiko diagnosis PJK pada pasien kanker paru sebesar 0,65 kali, namun tidak bermakna secara statistik (IK 95\%; $P=0,690$ ). Usia $<58$ tahun (rata-rata usia pada penelitian ini) meningkatkan risiko diagnosis PJK pada pasien kanker paru sebesar 1,16 kali lebih tinggi, namun tidak bermakna secara statistik (IK 95\% $=0,14$ 9,$75 ; P=0,889$ ) (Tabel 2).

Tabel 2. Hubungan diagnosis penyakit jantung koroner pada pasien kanker paru

\begin{tabular}{|c|c|c|c|c|}
\hline & \multicolumn{2}{|c|}{ PJK } & \multirow[t]{2}{*}{$P$} & \multirow{2}{*}{$\begin{array}{c}\text { OR } \\
\text { (IK 95\%) }\end{array}$} \\
\hline & Ada & $\begin{array}{l}\text { Tidak } \\
\text { ada }\end{array}$ & & \\
\hline \multicolumn{5}{|c|}{ Kalsifikasi Arteri Koroner } \\
\hline Ada & 13 & 5 & 0,003 & 111,48 \\
\hline Tidak ada & 2 & 20 & & $(5,10-2437,37)$ \\
\hline \multicolumn{5}{|c|}{ Riwayat Merokok } \\
\hline $\begin{array}{l}\text { Masih/bekas } \\
\text { perokok }\end{array}$ & 9 & 9 & 0,036 & $\begin{array}{c}50,28(1,29- \\
1963,29)\end{array}$ \\
\hline Tidak merokok & 6 & 16 & & \\
\hline \multicolumn{5}{|l|}{ Jenis Kelamin } \\
\hline Laki-laki & 7 & 12 & 0,055 & 0,02 \\
\hline Perempuan & 8 & 13 & & $(<0,01-1,09)$ \\
\hline \multicolumn{5}{|c|}{ Tipe Kanker Paru } \\
\hline KPKBSK & 14 & 24 & 0,285 & 4,19 \\
\hline KPSKK & 1 & 1 & & $(0,30-57,61)$ \\
\hline \multicolumn{5}{|c|}{ Stadium Kanker Paru } \\
\hline I & 0 & 0 & 0,295 & 3,24 \\
\hline
\end{tabular}

\begin{tabular}{lcccc}
\hline II & 0 & 0 & & $(0,36-29,32)$ \\
III & 0 & 0 & & \\
IVA & 6 & 6 & & \\
IVB & 9 & 19 & & \\
Usia & & & & \\
$<40$ tahun & 0 & 0 & 0,649 & 0,57 \\
$40-49$ tahun & 0 & 6 & & $(0,05-6,57)$ \\
$50-59$ tahun & 5 & 10 & & \\
$>60$ tahun & 10 & 7 & & \\
\hline
\end{tabular}

Akurasi kalsifikasi arteri koroner pada CT scan toraks untuk prediksi diagnosis PJK pada kanker paru

Berdasarkan hubungan bermakna antara temuan kalsifikasi arteri koroner pada CT scan toraks dengan diagnosis PJK pada kanker paru, maka penelitian dilanjutkan untuk mengetahui akurasi dari temuan kalsifikasi arteri koroner pada CT scan toraks untuk memprediksi adanya PJK pada kanker paru. Sensitivitas temuan kalsifikasi arteri koroner pada CT scan untuk diagnosis PJK pada kanker paru tersebut adalah $86,7 \%$ dengan spesifisitas $80,0 \%$, NPP $72,2 \%$ dan NPN 90,9\% (Tabel 3).

Tabel 3. Akurasi kalsifikasi arteri koroner sebagai prediktor diagnosis PJK pada pasien kanker paru

\begin{tabular}{lc}
\hline \multicolumn{1}{c}{ Variabel } & Nilai \\
\hline Sensitivitas & $86,7 \%$ \\
Spesifisitas & $80,0 \%$ \\
NPP & $72,2 \%$ \\
NPN & $90,9 \%$ \\
\hline
\end{tabular}

\section{PEMBAHASAN}

Pada penelitian ini, kami menemukan bahwa temuan kalsifikasi arteri koroner pada pemeriksaan CT scan meningkatkan risiko terjadinya PJK secara bermakna pada pasien kanker paru. Selain itu, kami menemukan bahwa perokok aktif dan bekas perokok juga dapat meningkatkan risiko tersebut secara bermakna.

Faktor lain yang meliputi usia, jenis kelamin, tipe kanker paru dan stadium kanker paru tidak terbukti berpengaruh secara bermakna terhadap risiko munculnya PJK pada pasien kanker paru. Studi ini merupakan studi pertama di Indonesia yang meneliti mengenai temuan kalsifikasi arteri koroner berdasarkan pemeriksan CT scan untuk digunakan sebagai prediktor terjadinya PJK pada pasien kanker paru. 
PJK merupakan salah satu penyakit kardiovaskular yang diduga memiliki hubungan dengan kanker paru. Penelitian Yuan dan $\mathrm{Li}$ menyatakan bahwa pasien kanker paru berisiko 1,66 kali lebih tinggi untuk memiliki penyakit kardiovaskular, termasuk PJK. Risiko tersebut meningkat hingga 2,17 kali lebih tinggi pada pasien kanker paru pada periode 6 bulan pasca diagnosis. ${ }^{1}$

Pada penelitian ini, kalsifikasi arteri koroner meningkatkan risiko terjadinya PJK pada pasien kanker paru sebesar 111,48 kali lebih tinggi secara bermakna (IK 95\%=5,10-2437,37; $P=0,003$ ). Secara umum, temuan kalsifikasi di arteri koroner pada pemeriksaan CT scan merupakan penanda radiologis keberadaan aterosklerosis arteri koroner. ${ }^{14,19}$ Multi-ethnic Study of Atherosclerosis (MESA) menunjukkan bahwa nilai kalsifikasi arteri koroner memiliki kemampuan prediksi yang baik, bahkan sebanding atau lebih baik dibandingkan kriteria klinis. ${ }^{20}$ Khusus pada pasien kanker paru, meta-analisis Fan dkk menyatakan bahwa kalsifikasi arteri koroner berhubungan positif dengan kejadian kardiovaskular sebesar 2,85 kali. ${ }^{21}$ Studi Rasmussen juga menunjukkan bahwa nilai kalsifikasi arteri koroner berdasarkan Agatston $>400$ menunjukkan risiko kematian yang lebih tinggi sebesar 3,8 kali lebih tinggi pada pasien kanker paru. ${ }^{22}$

Penelitian ini menunjukkan nilai sensitivitas, spesifisitas, NPP dan NPN yang cukup tinggi untuk temuan kalsifikasi arteri koroner berdasarkan pemeriksaan CT scan untuk diagnosis PJK pada pasien kanker paru. Hasil sensitivitas berada di angka $86,7 \%$, spesifisitas $80,0 \%$, NPP $72,2 \%$ dan NPN $90,9 \%$. Penelitian Pelandre dkk dengan menunjukkan nilai yang lebih tinggi dibandingkan penelitian ini dengan sensitivitas $95,98 \%$, spesifisitas 97,1\%, NPV 93,06\%, dan PPV 98,04\%. ${ }^{23}$

Rokok adalah faktor risiko utama kanker paru. Minimal 70 dari zat kimia dalam asap rokok diketahui berpotensi menyebabkan kanker paru pada hewan dan manusia. Rokok berpotensi menyebabkan kanker paru baik pada perokok primer maupun sekunder. ${ }^{24}$ Hubungan kausalitas antara PJK dan kanker paru juga diduga terutama disebabkan oleh rokok. ${ }^{1}$ Pada PJK dan kanker paru, merokok dapat menyebabkan peningkatan angka kematian akibat penyakit jantung iskemik hingga tiga kali lebih tinggi pada pasien kanker paru. Berhenti merokok juga diketahui berasosiasi dengan penurunan angka mortalitas akibat penyakit kardiovaskular pada pasien kanker paru. ${ }^{14}$

Penelitian ini menemukan bahwa pasien kanker paru yang masih merokok dan bekas perokok memiliki risiko 50,28 kali lebih tinggi untuk mengalami PJK secara bermakna (IK 95\%=1,291963,29; $P=0,036)$. Merokok diketahui menyebabkan pembentukan kalsium di arteri koroner hingga 10 tahun lebih cepat bila dibandingkan dengan orang yang tidak merokok. ${ }^{25}$ Studi Thun dkk menunjukkan bahwa pasien kanker paru yang merokok memiliki risiko meninggal dunia akibat penyakit jantung iskemik yang lebih tinggi 3 kali lipat dibandingkan dengan pasien kanker paru yang tidak merokok. ${ }^{26}$ Bila tidak ada faktor risiko lain, pasien yang merokok sudah termasuk risiko sedang untuk terjadinya PJK pada pasien kanker paru. ${ }^{14}$

Terdapat enam (15\%) pasien kanker paru yang tidak merokok, namun memiliki PJK pada penelitian ini. Kemoterapi dan radioterapi yang diberikan pada pasien kanker paru diketahui merupakan salah satu faktor risiko munculnya penyakit kardiovaskular, termasuk PJK, pada pasien kanker paru, selain rokok. ${ }^{5}$ Semua subjek pada penelitian ini merupakan pasien kanker paru stadium IV dimana kemoterapi dan radioterapi merupakan pilihan tatalaksana utama, sehingga berpotensi mempengaruhi risiko munculnya PJK. Studi Wang dkk dan Dess dkk menemukan bahwa radioterapi meningkatkan risiko PJK pada pasien KPKBSK. ${ }^{27,28}$ Studi Dieckmann dkk, Starling dkk dan De Bruin dkk menemukan bahwa kemoterapi berisiko meningkatkan penyakit kardiovaskular pada beberapa jenis keganasan. $29,30,31$

Penelitian ini menunjukkan bahwa usia bukanlah faktor risiko bermakna untuk terjadinya PJK pada pasien kanker paru (OR=0,57; IK $95 \%=0,05-6,57 ; P=0,649)$. Kanker paru dan PJK merupakan penyakit yang berpotensi terjadi bersamaan pada usia tertentu karena terdapat faktor etiologi yang sama serta proses perjalanan penyakit 
yang berpotensi terjadi bersamaan. ${ }^{32,33}$ Pada perokok, proses aterosklerosis yang berpotensi menjadi PJK dapat terjadi bersamaan dengan proses patologis pada sel-sel paru yang berpotensi menjadi kanker paru. ${ }^{34}$

Penelitian ini menyatakan bahwa jenis kelamin bukan faktor risiko bermakna terjadinya PJK pada pasien kanker paru (OR=0,02; IK 95\% <0,01$1,09 ; P=0,055)$. Studi Zoller dkk menunjukkan bahwa mayoritas PJK pada pasien kanker lebih sering terjadi pada laki-laki dibandingkan perempuan $(63,9: 36,1)^{2}$ dan kondisi ini tidak berbeda secara bermakna dengan kondisi tanpa kanker $(60,0: 40,0)$. Studi Gan dkk menunjukkan bahwa jenis kelamin pada pasien dengan kanker paru bukan faktor yang membedakan risiko penyakit jantung iskemik. ${ }^{24}$

\section{Keterbatasan Penelitian}

Salah satu keterbatasan penelitian ini adalah desain studi potong lintang, sehingga tidak dapat dicari hubungan sebab akibat antara variabel yang diperiksa. Penelitian ini hanya mampu mendapatkan korelasi antara temuan kalsifikasi arteri koroner dengan diagnosis penyakit jantung koroner pada pasien kanker paru.

Meskipun pada analisis multivariat telah disertakan pelbagai variabel yang dapat menjadi perancu korelasi antara temuan kalsifikasi arteri koroner berdasarkan CT scan dengan penyakit jantung koroner, tetap ada kemungkinan adanya faktor lain yang dapat mempengaruhi hasil tersebut, namun tidak diambil datanya dan diikutsertakan dalam analisis.

\section{KESIMPULAN}

Temuan kalsifikasi arteri koroner berdasarkan pemeriksaan CT scan dapat menjadi prediktor diagnosis penyakit jantung koroner pada pasien kanker paru di masa depan. Kalsifikasi arteri koroner perlu dianalisis juga pada setiap CT scan pasien dengan kanker paru untuk memperkirakan risiko penyakit jantung koroner pada pasien-pasien tersebut, terutama bagi pasien yang masih merokok dan bekas perokok.

\section{DAFTAR PUSTAKA}

1. Yuan M, Li QG. Lung cancer and risk of cardiovascular disease: a meta-analysis of cohort studies. J Cardiothorac Vasc Anesth. 2018;32(1):e25-e27.

2. Zoller H, Ji J, Sundquist J, Sundquist K. Risk of coronary heart disease in patients with cancer: a nationwide follow-up study from Sweden. Eur J Cancer. 2012;48(1):121-128.

3. Armenian $\mathrm{SH}, \mathrm{Xu}, \mathrm{L}, \mathrm{Ky} \mathrm{B}$, Sun $\mathrm{C}$, Farol LT, Pal SK, et al. Cardiovascular disease among survivors of adult-onset cancer: a communitybased restrospective cohort study. J Clin Oncol;34(10):1122-30.

4. van Herk Sukel MPP, Shantakumar S, Penningvan Beest FJA, Kamphuisen PW, Majoor CJ, Overbeek LIH, et al. Pulmonary embolism, myocardial infarction, and ischemic stroke in lung cancer patients: results from a longitudinal study. Lung;191(5):501-9.

5. Yoon DW, Shin DW, Cho JH, Yang JH, Jeong $\mathrm{SM}, \mathrm{Han} \mathrm{K}$, et al. Increased risk of coronary heart disease and stroke in lung cancer survivors: a Korean nationwide study of 20.458 patients. Lung Cancer. 2019;136: 5-21.

6. Hedley AJ, McGhee SM, Repace JL, Wong LC, Yu MYS, Wong T, et al. Risks for heart disease and lung cancer from passive smoking by workers in the catering industry. Toxicological Sciences. 2006;90(2):539-48.

7. Goldkorn T, Filosto S, Chung S. Lung injury and lung cancer caused by Cigarette Smoke-Induced Oxidative Stress: Molecular Mechanisms and Therapeutic Opportunities Involving the Ceramide-Generating Machinery and Epidermal Growth Factor Receptor. Antioxid Redox Signla. 2014;21(15):2149-74.

8. Walser T, Cui X, Yanagawa J, Lee JM, Heinrich $\mathrm{E}$, Lee G, et al. Smoking and lung cancer: the role of inflammation. Proc Am Thorac Soc. 2008;5(8):811-5.

9. Kadara H, Scheet P, Wistuba II, Spira AE. Early events in the molecular pathogenesis of lung cancer. Cancer Prev Res; 9(7): 518-26. 
10. Malakar AK, Choudhury D, Halder B, Paul P, Uddin A, Chakraborty S. A review on coronary artery disease, its risk factors, and therapeutics. Cell Physiol. 2019;234(10):1-12.

11. Stallones RA. The association between tobacco smoking and coronary heart disease. Int $\mathrm{J}$ Epidemiol. 2015;44(3):735-43.

12. Nakamura K, Barzi F, Huxley R, Lam TH, Suh I, Woo J, et al. Asia Pacific Cohort Studies Collaboration. does cigarette smoking exacerbate the effect of total cholesterol and high-density lipoprotein cholesterol on the risk of cardiovascular diseases? Heart. 2009;95:909_ 16.

13. Messner B, Bernhard D. Smoking and cardiovascular disease: mechanisms of endothelial dysfunction and early atherogenesis. Arterioscler Thromb Vasc Biol. 2014;34(3):50915.

14. Ravenel JG, Nance JW. Coronary artery calcification in lung cancer screening. Transl Lung Cancer Res. 2018;7(3):361-7.

15. Bastarrika G, Lee YS, Huda W, Ruzsics B, Costello P, Schopf UJ. CT of coronary artery disease. Radiology. 2009;253(2):317-38.

16. Sun Z. Cardiac CT imaging in coronary artery disease: current status and future directions. Quant Imaging Med Surg. 2012;2(2):98-105.

17. Liu W, Zhang Y, Yu C, Ji Q, Cai M, Zhao Y, et al. Current understanding of coronary artery calcification. J Geriatr Cardiol. 2015;12(6):66875.

18. Morri H, Torii S, Kutyna M, Sakamoto A, Finn AV, Virmani R. Coronary artery calcification and its progression: what does it really mean? JACC: Cardiovasc Imaging. 2018;11(1):127-42.

19. Gupta VA, Leung SW, Winkler MA, Sorrell VL. Identifying coronary artery calcification on nongated computed tomography scans. J Vis Exp. 2018;138:57918.

20. Detrano R, Guerci AD, Car JJ, Bild DE, Burke G, Folosom AR, et al. Coronary calcium as a predictor of coronary events in four racial or ethnic groups. N Engl J Med. 2008;358(13):133645.
21. Fan L, Fan K. Lung cancer screening CT-based coronary artery calcification in predicting cardiovascular events: a systematic review and meta-analysis. Medicine (Baltimore). 2018;97(20):e10461.

22. Rasmussen T, Kober L, Abdulla J, Pedersen JH, Wille MMW, Dirksen A, et al. Coronary artery calcification detected in lung cancer screening predicts cardiovascular death. Scand Cardiovasc J. 2015;49(3):159-67.

23. Pelandre GL, Sanches NMP, Nacif MS, Marchiori E. Detection of coronary artery calcification with nontriggered computed tomography of the chest. Radiol Bras. 2018;51(1):8-12.

24. Gan Q, Smith KR, Hammond SK, Hu T. Disease burden of adult lung cancer and ischaemic heart disease from passive tobacco smoking in China. Tob Control. 2007;16(6):417-22.

25. Lehmann N, Mohlenkamp S, Mahabadi AA, Schmermund A, Roggenbuck U, Seibel R, et al. Effect of smoking and other traditional risk factors on the onset of coronary artery calcification: results of the Heinz Nixdorf recall study. Atherosclerosis. 2014;232:339-45.

26. Thun MJ, Carter BD, Feskanich D, Freedman ND. 50-year trends in smoking-related mortality in the United States. $N$ Engl $J$ Med. 2013;368:351-64.

27. Wang K, Eblan MJ, Deal AM, Lipner M, Zagar TM, Wang $Y$, et al. Cardiac toxicity after radiotherapy for stage iii non-small-cell lung cancer: pooled analysis of dose-escalation trials delivering 70 to 90 gy. J Clin Oncol. 2017;35(13):1387-94.

28. Dess RT, Sun Y, Matuszak MM. Cardiac events after radiation therapyL combined analysis of prospective multicenter trials for locally advanced non-small-cell lung cancer. J Clin Oncol. 2017;35:1395-1402.

29. Dieckmann KP, Gerl A, Witt J, Hartmann JT. Myocardial infarction and other major vascular events during chemotherapy for testicular cancer. Ann Oncol. 2010;21:1607-11.

30. Starling N, Rao S, Cunningham D. Thromboembolism in patients with advanced 
gastroesophageal cancer treated with anthracycline, platinum, and fluoropyrimidine combination chemotherapy: a report form the UK National Cancer Research Institute Upper Gastrointestinal Clinical Studies Group. J Clin Oncol. 2009;27:3786-93.

31. De Bruin MI, Dorrestein LD, van $t$ Veer MB. Increased risk of stroke and transient ischemic attack in 5-year survivors of Hodgkin lymphoma. J Natl Cancer Inst. 2009;101:928-37.

32. Kravchenko J, Berry M, Arbeev K, Lyerly, HK, Yashin A, Akushevich I. Cardiovascular comorbidities and survival of lung cancer patients: Medicare data based analysis. Lung Cancer. 2015;88(1):85-93.

33. Ambrose JA, Barua RS. The pathophysiology of cigarette smoking and cardiovascular disease: an update. J Am Coll Cardiol. 2004;43:1731-7.

34. Whitlock MC, Yeboah J, Burke GL, Chen H, Klepin HD, Hundley WG. Cancer and its association with the development of coronary artery calcification: an assessment from the multi-ethnic study of atherosclerosis. J Am Heart Assoc. 2016;4(11):e002533. 